medRxiv preprint doi: https://doi.org/10.1101/2021.06.03.21258309; this version posted June 8, 2021. The copyright holder for this preprint

(which was not certified by peer review) is the author/funder, who has granted medRxiv a license to display the preprint in perpetuity.

It is made available under a CC-BY-NC-ND 4.0 International license .

\title{
Lead exposure and serum metabolite profiles in pregnant women in Mexico City
}

Megan M. Niedzwiecki ${ }^{\star a}$, Shoshannah Eggers ${ }^{a}$, Anu Joshi ${ }^{a}$, Georgia Dolios $^{a}$, Alejandra

Cantoral $^{b}$, Héctor Lamadrid-Figueroa ${ }^{c}$, Chitra Amarasiriwardena ${ }^{a}$, Martha M. Téllez-Rojo ${ }^{c}$,

Robert O. Wright ${ }^{a}$, Lauren Petrick ${ }^{a}$

Institutional Addresses: a. Environmental Medicine and Public Health, Icahn School of

Medicine at Mount Sinai, 1 Gustave L. Levy Place, New York, NY, USA; b. Health Department,

Universidad Iberoamericana, Mexico City, Mexico; c. National Institute of Public Health,

Cuernavaca, Morelos, Mexico.

${ }^{*}$ Corresponding author

Key Words: $\mathrm{Pb}$ exposure, pregnancy, metabolome, bone $\mathrm{Pb}$, caffeine, fatty acids 
medRxiv preprint doi: https://doi.org/10.1101/2021.06.03.21258309; this version posted June 8, 2021. The copyright holder for this preprint (which was not certified by peer review) is the author/funder, who has granted medRxiv a license to display the preprint in perpetuity. It is made available under a CC-BY-NC-ND 4.0 International license .

\section{Abstract}

Background: Lead $(\mathrm{Pb})$ exposure is a global health hazard causing a wide range of adverse health outcomes. Yet, the mechanisms of $\mathrm{Pb}$ toxicology remain incompletely understood, especially during pregnancy. To uncover biological pathways impacted by $\mathrm{Pb}$ exposure, this study investigated serum metabolomic profiles during the third trimester of pregnancy that are associated with blood $\mathrm{Pb}$ and bone $\mathrm{Pb}$.

Methods: We used data and specimens collected from 99 women enrolled in the Programming Research in Obesity, Growth, Environment, and Social Stressors birth cohort based in Mexico City. Maternal Pb exposure was measured in whole blood samples from the third trimester of pregnancy and in the tibia and patella bones at 1 month postpartum. Third-trimester serum samples underwent metabolomic analysis; metabolites were identified based on matching to an in-house analytical standard library. A metabolome-wide association study was performed with all three $\mathrm{Pb}$ measurements using multiple linear regression models, adjusted for confounders and batch effects. Class enrichment analyses were also conducted.

Results: The median (interquartile range) blood Pb concentration was 2.9 (2.6) $\mu \mathrm{g} / \mathrm{dL}$. Median bone $\mathrm{Pb}$, measured in the patella and tibia, were $2.5(7.3) \mu \mathrm{g} / \mathrm{g}$ and $3.6(9.5) \mu \mathrm{g} / \mathrm{g}$, respectively. Of 248 total metabolites identified in serum, 31 were associated with blood $\mathrm{Pb}(\mathrm{p}<0.05)$. Class enrichment analysis identified significant overrepresentation of metabolites classified as fatty acids and conjugates, amino acids and peptides, and purines. Tibia and patella $\mathrm{Pb}$ were associated with 14 and 11 metabolites, respectively $(p<0.05)$. Comparing results from bone and blood $\mathrm{Pb}$, glycochenodeoxycholic acid and glycocholic acid were negatively associated with blood $\mathrm{Pb}$ and tibia $\mathrm{Pb}$, while 5-aminopentanoic acid and 7-methylguanine were negatively associated with blood $\mathrm{Pb}$ and patella $\mathrm{Pb}$. One metabolite, 5-aminopentanoic acid, was associated with all three $\mathrm{Pb}$ measures.

Conclusion: This study identified serum metabolites in pregnant women associated with $\mathrm{Pb}$ measured in blood (31 metabolites) and bone (tibia: 14 metabolites, patella: 11 metabolites). 
medRxiv preprint doi: https://doi.org/10.1101/2021.06.03.21258309; this version posted June 8, 2021. The copyright holder for this preprint (which was not certified by peer review) is the author/funder, who has granted medRxiv a license to display the preprint in perpetuity. It is made available under a CC-BY-NC-ND 4.0 International license .

These findings provide insights on the metabolic profile around $\mathrm{Pb}$ exposure in pregnancy and may provide important links to guide detailed studies of toxicological effects for both mothers and children. 
medRxiv preprint doi: https://doi.org/10.1101/2021.06.03.21258309; this version posted June 8, 2021. The copyright holder for this preprint (which was not certified by peer review) is the author/funder, who has granted medRxiv a license to display the preprint in perpetuity. It is made available under a CC-BY-NC-ND 4.0 International license .

\section{Background}

Lead $(\mathrm{Pb})$ exposure is a persistent global health hazard, with no safe exposure threshold (1). $\mathrm{Pb}$ is a naturally occurring non-essential element, and human industrial practices can promote $\mathrm{Pb}$ exposures through the contamination of dust, food, and water (2). Once ingested, $\mathrm{Pb}$ often substitutes for calcium $\left(\mathrm{Ca}^{2+}\right)$ in the human body and can accumulate in bone, where it is stored long-term and can re-enter the bloodstream during periods of bone remodeling (3). $\mathrm{Pb}$ exposures are linked to a wide array of detrimental health outcomes $(2,4,5)$, including neurotoxicity, reduced kidney function, anemia, joint weakness, hypertension, reduced immune function, and reproductive complications.

Children are particularly susceptible to the effects of $\mathrm{Pb}$ exposures: for a given $\mathrm{Pb}$ exposure, the relative exposure in children is larger by body mass than in adults, and children have higher soft tissue $\mathrm{Pb}$ absorption $(3,6,7)$. Further, children have a more permeable bloodbrain barrier than adults, making the neurotoxic effects of $\mathrm{Pb}$ particularly pronounced (3). Finally, there are multiple critical neurodevelopmental windows during childhood wherein $\mathrm{Pb}$ exposure may lead to life-long adverse neurological effects $(8,9)$. Despite these significant health concerns, the mechanisms of $\mathrm{Pb}$ toxicity are not fully understood. Novel approaches to investigating $\mathrm{Pb}$ metabolism and toxicology may promote new avenues for discovering these mechanisms. Additionally, further examination of $\mathrm{Pb}$ exposure during pregnancy is particularly crucial, as exposure during this period can exert harmful effects in both mothers and children.

One powerful approach to uncover the biological impacts of $\mathrm{Pb}$ exposure is through metabolomics. Measuring metabolites in biological samples, such as plasma or serum, provides a snapshot of metabolic function, enabling the investigation of biological responses to exposures, including Pb. Unlike other 'omic technologies (e.g., genomics, transcriptomics, etc.) that capture the potential for phenotypic changes, metabolomics shows the actual state of metabolic function. Therefore, metabolomics can reveal the metabolic links between $\mathrm{Pb}$ 
medRxiv preprint doi: https://doi.org/10.1101/2021.06.03.21258309; this version posted June 8, 2021. The copyright holder for this preprint (which was not certified by peer review) is the author/funder, who has granted medRxiv a license to display the preprint in perpetuity. It is made available under a CC-BY-NC-ND 4.0 International license .

exposure and downstream health outcomes by investigating metabolites and pathways strongly associated with $\mathrm{Pb}$ exposure.

Metabolomics analyses of $\mathrm{Pb}$ exposures are relatively sparse. The few metabolomics studies of $\mathrm{Pb}$ have primarily been conducted in animals, adult males, and highly-exposed populations. In a study investigating the effects of $\mathrm{Pb}$ exposure on the gut microbiome and blood metabolome in 8-week-old female mice, Gao et al. found that Pb exposure altered multiple metabolomic pathways including nitrogen metabolism, oxidative stress, vitamin $\mathrm{E}$, and bile acids (10). A similar dosing study in 8-month-old rats found that $\mathrm{Pb}$ exposure reduced levels of butyryl-L-carnitine and ganglioside GD2 (d18:0/20:0) and increased levels of metabolites associated with oxidative stress pathways (11). In an epidemiologic investigation of the urinary metabolome of highly-exposed participants residing near a $\mathrm{Pb}$ acid battery recycling plant, blood $\mathrm{Pb}$ was associated with several metabolic pathways, including porphyrin, amino acid, and chlorophyll metabolism, heme biosynthesis, and ATP-binding cassette transporters (12). Another epidemiologic analysis in the Veterans Administration Normative Aging Study found several blood metabolites associated with blood $\mathrm{Pb}$, including amino acids, lipids, and metabolites involved in oxidative stress and immune pathways (13). Taken together, these results indicate that biologically-relevant metabolic changes occur with $\mathrm{Pb}$ exposure. While some findings are consistent (amino acids, oxidative stress), numerous factors, including the timing, level, and population(s) of $\mathrm{Pb}$ exposure, may affect metabolomic responses. Because pregnancy is a uniquely important period of the lifecourse, understanding $\mathrm{Pb}$-associated metabolomic changes in pregnant women-particularly in response to low-level $\mathrm{Pb}$ exposures in ranges commonly observed in human populations-is critical to broadly understand the impacts of $\mathrm{Pb}$ exposure on human health.

In observational studies, $\mathrm{Pb}$ can be measured in a variety of samples-including hair, nails, urine, blood, and bone-with each matrix capturing a different window of exposure. Blood and bone, which are considered the gold standards for $\mathrm{Pb}$ measurement, capture short- and 
medRxiv preprint doi: https://doi.org/10.1101/2021.06.03.21258309; this version posted June 8, 2021. The copyright holder for this preprint (which was not certified by peer review) is the author/funder, who has granted medRxiv a license to display the preprint in perpetuity. It is made available under a CC-BY-NC-ND 4.0 International license .

long-term exposure, respectively: $\mathrm{Pb}$ has a half-life from 1 week to 2 months in blood, depending on age and exposure history, and 5 to 20 years in bone (14). Previous metabolomics studies primarily measured $\mathrm{Pb}$ in blood, which captures relatively recent $\mathrm{Pb}$ exposure. Metabolomic analyses in relation to bone $\mathrm{Pb}$ will add important information to the literature on the biological impacts of longer-term $\mathrm{Pb}$ exposure.

This study investigated serum metabolomic profiles during the third trimester of pregnancy to provide insights on the biological impacts of short- and long-term $\mathrm{Pb}$ exposures during this critically important period. We profiled metabolites and measured Pb levels in thirdtrimester blood samples and collected postpartum bone $\mathrm{Pb}$ measures for 99 women in the Programming Research in Obesity, Growth, Environment, and Social Stressors (PROGRESS) cohort based in Mexico City, Mexico.

\section{Methods}

\section{Study subjects}

The PROGRESS cohort recruited women who were pregnant and receiving prenatal care through the Mexican Social Security System (Instituto Mexicano del Seguro Social - IMSS) between July 2007 and February 2011; in total, there were 948 women with live births. Women were eligible to participate in the study if they were $\geq 18$ years old and $<20$ weeks of gestation, planned to stay in Mexico City for the next 3 years, had access to a telephone, had no medical history of heart or kidney disease, did not consume alcohol daily, and did not use any steroid or anti-epilepsy medications. Procedures were approved by institutional review boards at the Harvard School of Public Health, Icahn School of Medicine at Mount Sinai, and the Mexican National Institute of Public Health. Women provided written informed consent in Spanish. For the current study, 99 women with available serum samples stored at $-80^{\circ} \mathrm{C}$ from the third trimester of pregnancy were randomly selected from the full cohort for metabolomics analysis. 
medRxiv preprint doi: https://doi.org/10.1101/2021.06.03.21258309; this version posted June 8, 2021. The copyright holder for this preprint (which was not certified by peer review) is the author/funder, who has granted medRxiv a license to display the preprint in perpetuity. It is made available under a CC-BY-NC-ND 4.0 International license .

\section{Lead $(\mathrm{Pb})$ measurements}

All Pb measurements were previously analyzed as described (15). In short, blood specimens in trace metal-free tubes were analyzed using an Agilent 8800 ICP Triple Quad in MS/MS mode in the trace metals laboratory at the Icahn School of Medicine at Mount Sinai. The limit of detection was $<0.2 \mu \mathrm{g} / \mathrm{dL}$, and the instrument precision was approximately $5 \%$ relative standard deviation. At 1 month postpartum, mother's tibia (cortical bone) and patella (trabecular bone) $\mathrm{Pb}$ concentrations were measured using a K-shell X-ray fluorescence instrument, a noninvasive, low-radiation-dose method of measuring bone lead content (16). We estimated lead concentration for 30 min for each leg and the measures were averaged by the inverse of the proportion of the measurement error corresponding to each determination. Bone $\mathrm{Pb}$ content is thought to provide an indicator of exposure over the span of decades; in particular, tibia measurements reflect longer time spans (>10 years) compared to patella (1-5 years) (17).

\section{Metabolomics analysis}

Stored serum samples were thawed on ice and vortexed, and 50-uL aliquots were transferred to a microcentrifuge tube. $150 \mathrm{uL}$ of methanol containing internal standards was added, and the sample vortexed then incubated at $-20^{\circ} \mathrm{C}$ for $30 \mathrm{~min}$. Samples were centrifuged, the supernatant dried using a Savant SC250EXP SpeedVac concentrator at $35^{\circ} \mathrm{C}$ for 90 minutes and stored at $-80^{\circ} \mathrm{C}$ until analysis. Before liquid chromatography high-resolution mass spectrometry (LC-HRMS) analysis, dried extracts were reconstituted in $60-\mathrm{uL}$ of $80 \%$ acetonitrile or $100 \%$ methanol for analysis using zwitterionic hydrophilic interaction liquid chromatography (ZIC-HILIC) or reverse phase (RP) LC connected to HRMS in positive and negative modes, respectively, as described elsewhere $(18,19)$. An additional 10-uL aliquot from each sample was combined for use as a pooled quality control sample ("pooled QC") and processed similarly. Following the same protocol, matrix blanks (replacing the plasma with 
medRxiv preprint doi: https://doi.org/10.1101/2021.06.03.21258309; this version posted June 8, 2021. The copyright holder for this preprint (which was not certified by peer review) is the author/funder, who has granted medRxiv a license to display the preprint in perpetuity. It is made available under a CC-BY-NC-ND 4.0 International license .

water) and multiple pooled QCs were extracted. Samples were analyzed in a randomized order in four analytical batches, with pooled QCs injected routinely throughout the run.

Metabolites were identified based upon in-house database matching considering retention time, accurate mass, and MS/MS matching (when available) with pure standards analyzed under the same conditions. Peaks were identified and integrated using the Personal Chemical Database Library and Profinder software (Agilent Technologies, Santa Clara, USA). There were 139 metabolites and 115 metabolites detected by HILIC and RP chromatography methods, respectively. Of these, seven metabolites were identified using both methods; only the higher intensity value was retained for analyses. Therefore, the combined dataset had 248 metabolites of interest. Metabolites were evaluated for missing values and only retained if they had more than $50 \%$ non-missing values. Missing values were imputed with the minimum value of the metabolite divided by the square root of 2 . Imputed data were then $\log _{2}$-transformed to remove heteroscedasticity (unequal variability) in the metabolite intensities.

\section{Covariates}

Age and educational attainment were ascertained at enrollment. Since only one woman in the cohort reported smoking tobacco during pregnancy, environmental tobacco smoke exposure during pregnancy was characterized as the report of any tobacco smoker in the home during the second or third trimester of pregnancy. Body mass index (BMI) was determined using height (in meters [m]) and weight (in kilograms [kg]) ascertained at the third-trimester study visit. The season of the last menstrual period was defined according to weather patterns in Mexico City as dry/cold (January-February; November-December), dry/warm (March-April) and rainy (May-October). Since metabolite levels can vary by laboratory batch, models also accounted for the metabolomics batch assignment as a categorical variable.

\section{Statistical analysis}


medRxiv preprint doi: https://doi.org/10.1101/2021.06.03.21258309; this version posted June 8, 2021. The copyright holder for this preprint (which was not certified by peer review) is the author/funder, who has granted medRxiv a license to display the preprint in perpetuity. It is made available under a CC-BY-NC-ND 4.0 International license .

A metabolome-wide association study approach was used to identify metabolites associated with blood and bone $\mathrm{Pb}$ measures. Using this approach, multiple linear regression models were constructed for each $\mathrm{Pb}$ variable (blood $\mathrm{Pb}$, tibia $\mathrm{Pb}$, or patella $\mathrm{Pb}$ ) as the main predictor of $\log _{2}$-transformed metabolite intensities, adjusting for all covariates listed above. For significant findings, the patterns of the associations were examined using bivariate scatterplots and locally estimated scatterplot smoothing regression. For bone $\mathrm{Pb}$ variables, negative instrument values were included in analyses; sensitivity analyses were conducted in which negative values were imputed with simulated values between 0 and the detection limit $(2 \mu \mathrm{g} / \mathrm{g})$ generated from a uniform distribution.

To identify significant metabolites while accounting for the high correlation among the metabolite measurements, we implemented the "number of effective tests" adjustment approach previously used in metabolomics studies $(13,20,21)$. Briefly, we used principal components analysis to identify the number of principal components (PCs) that explain $75 \%, 95 \%$, and $99 \%$ of the variance in metabolite intensities, then used these numbers to calculate adjusted $p$-values $(a / m)$, where a reflects the nominal $p$-value threshold of 0.05 , and $m$ reflects the number of PCs that explain the defined level of variance. Herein, we calculated effective number of test (ENT) thresholds of $75 \%$ (ENT75\%: 0.05/24=0.002083), 95\% (ENT95\%: 0.05/60=0.00083), and 99\% (ENT99\%: 0.05/84=0.000595).

For biological interpretation of the blood $\mathrm{Pb}$ results, we input metabolites into MetaboAnalyst (22) to perform class- and pathway-based enrichment analyses. We identified significant metabolite classes and metabolic pathways using the main-class chemical structure and the Small Molecule Pathway Database (23) pathway-based metabolite set libraries, respectively. For co-eluting metabolites, only the first listed metabolite was used as input in enrichment analyses.

\section{Results}


medRxiv preprint doi: https://doi.org/10.1101/2021.06.03.21258309; this version posted June 8, 2021. The copyright holder for this preprint (which was not certified by peer review) is the author/funder, who has granted medRxiv a license to display the preprint in perpetuity. It is made available under a CC-BY-NC-ND 4.0 International license .

The study sample consisted of 99 randomly-selected pregnant women from the PROGRESS cohort with complete data on exposure and covariates (Table 1). The median (interquartile range [IQR]) age of these women was 27.7 (6.8) years, and 63\% completed a high school education or greater.

The median (IQR) Pb concentration in third-trimester blood samples was $2.9(2.6) \mu \mathrm{g} / \mathrm{dL}$ (Table 1). These levels are higher than those observed in non-pregnant women of childbearing age measured in NHANES during a similar time period (24). Current guidelines for medical management of lead-exposed adults recommend that pregnant women avoid occupations and avocational exposures that may result in blood $\mathrm{Pb}$ levels $>5 \mu \mathrm{g} / \mathrm{dL}$ (25). In our study, nineteen mothers had blood $\mathrm{Pb}$ concentrations above the CDC action level of $\geq 5 \mu \mathrm{g} / \mathrm{dL}$ for pregnant women; among these women, three had Pb levels of concern ( $\geq 10 \mu \mathrm{g} / \mathrm{dL})(26)$.

Bone patella and tibia $\mathrm{Pb}$ levels measured at 1 month postpartum-reflecting long-term $\mathrm{Pb}$ exposures from 1-5 years and >10 years, respectively-were 2.5 (7.3) $\mu \mathrm{g} / \mathrm{g}$ and 3.6 (9.5) $\mu \mathrm{g} / \mathrm{g}$, respectively (Table 1 ). The $\mathrm{Pb}$ levels in patella and tibia were strongly correlated (Pearson's $\mathrm{r}=0.51$ ), while, as expected, bone $\mathrm{Pb}$ measures were less strongly correlated with blood $\mathrm{Pb}$ (patella and blood $\mathrm{Pb}, \mathrm{r}=0.34$; tibia and blood $\mathrm{Pb}, \mathrm{r}=0.15)$ (Figure 1).

We detected a total of 248 metabolites in third-trimester serum samples. Of these, 31 metabolites were associated with third-trimester blood $\mathrm{Pb}$ at nominal significance $(\mathrm{p}<0.05)$ (Table 2), and 2-hydroxybutyrate and hypoxanthine was negatively associated at ENT95\% and ENT75\% thresholds, respectively. Class-based enrichment analyses of these 31 metabolites identified significant overrepresentation (Holm-Bonferroni $\mathrm{p}<0.05$ ) of metabolites classified as fatty acids and conjugates, amino acids and peptides, and purines (noted with asterisks in

\section{Table 2).}

Additionally, pathway-based enrichment analysis identified the alpha linolenic acid and linoleic acid metabolic pathway (Figure 2), which contained five metabolites that were negatively associated with blood $\mathrm{Pb}$. We note that linoleic acid and the $n-3$ fatty acid 
medRxiv preprint doi: https://doi.org/10.1101/2021.06.03.21258309; this version posted June 8, 2021. The copyright holder for this preprint (which was not certified by peer review) is the author/funder, who has granted medRxiv a license to display the preprint in perpetuity. It is made available under a CC-BY-NC-ND 4.0 International license .

docosahexaenoic acid (DHA), the latter of which is synthesized in this pathway, were also negatively associated with blood $\mathrm{Pb}$ at marginal significance (linoleic acid: estimate [SE], -0.043 [0.022], $p=0.06$; DHA: estimate [SE], -0.038 [0.020], $p=0.06)$.

We also examined third-trimester serum metabolites associated with patella and tibia $\mathrm{Pb}$, which identified 14 and 11 metabolites, respectively, at $\mathrm{p}<0.05$ (Table 3); of these, two -5aminopentanoic acid and L-arginine—were negatively associated with both bone $\mathrm{Pb}$ measures. Betaine was positively associated with patella $\mathrm{Pb}$ at ENT99\%, and 1-linoleoylglycerol was positively associated with tibia $\mathrm{Pb}$ at ENT95\%. In sensitivity analyses, results did not materially change when negative instrument values for bone $\mathrm{Pb}$ were imputed with positive values below the limit of detection (data not shown).

Finally, we compared metabolites significantly associated with bone and blood $\mathrm{Pb}$. Two metabolites, glycochenodeoxycholic acid and glycocholic acid, were negatively associated with blood $\mathrm{Pb}$ and tibia $\mathrm{Pb}$, while 5-aminopentanoic acid and 7-methylguanine were negatively associated with blood $\mathrm{Pb}$ and patella $\mathrm{Pb}$. Further, one metabolite, 5-aminopentanoic acid, was associated with all three measures (Figure 3).

\section{Discussion}

$\mathrm{Pb}$ exposure is associated with many deleterious effects, but the complex downstream biological perturbations that result from $\mathrm{Pb}$ exposure, particularly at lower levels and during pregnancy, are not well understood. Metabolomics, which provides a global, unbiased measurement of circulating metabolites, enables discovery of metabolites and underlying mechanisms associated with exposures. However, to date, population studies on metabolomics of $\mathrm{Pb}$ exposures are sparse and have focused on high-exposure populations (12) or have been performed on aging adult men (13). Our study on 99 pregnant women is the first to investigate third-trimester serum metabolomics with both blood $\mathrm{Pb}$ and bone $\mathrm{Pb}$ contents to unravel biological impacts during pregnancy of both acute and long-term $\mathrm{Pb}$ exposure. 
medRxiv preprint doi: https://doi.org/10.1101/2021.06.03.21258309; this version posted June 8, 2021. The copyright holder for this preprint (which was not certified by peer review) is the author/funder, who has granted medRxiv a license to display the preprint in perpetuity. It is made available under a CC-BY-NC-ND 4.0 International license .

Lead exposure through inhalation and ingestion results in absorption into the blood, wherein plasma levels reflect the most rapidly exchangeable fraction of $\mathrm{Pb}$ in the bloodstream. This fraction is assumed to be associated with the toxic effects of $\mathrm{Pb}$ (27). In addition, around $95 \%$ of the total $\mathrm{Pb}$ burden is contained within bone, which reflects integrated or cumulative $\mathrm{Pb}$ exposure (28). During rapid bone turnover, such as in pregnancy, $\mathrm{Pb}$ from bone may migrate into plasma, influencing plasma Pb levels (29). Indeed, we observed a greater number of metabolites associated with blood $\mathrm{Pb}$ (31 metabolites) than bone $\mathrm{Pb}$ (14 and 11 metabolites in patella and tibia, respectively) in study participants, coinciding with weak to moderate correlations between the three Pb measures (Pearson's $r=0.15-0.51$ ). The third trimester is the period during pregnancy that contains the greatest mobilization of $\mathrm{Pb}$ from maternal bone and fastest fetal growth $(30,31)$. Since fetuses are directly exposed to the maternal $\mathrm{Pb}$ fraction via umbilical cord transfer (32), higher exposure to $\mathrm{Pb}$ during the third trimester may coincide with adverse effects on fetal development. Thus, maternal exposure metrics of $\mathrm{Pb}$ are a proxy for fetal exposure, and altered metabolomes that we observed herein may reflect both systemic biological responses (tibia and patella bone $\mathrm{Pb}$ ) and acute responses (blood $\mathrm{Pb}$ ) with potential to impact both maternal and fetal health.

Our results show that cumulative $\mathrm{Pb}$ exposures measured in bone reflected different metabolite association patterns than acute $\mathrm{Pb}$ exposures measured in third-trimester serum (Tables 2 and 3). However, two bile acids, glycochenodeoxycholic acid and glycocholic acid, were negatively associated with both blood $\mathrm{Pb}$ and tibia $\mathrm{Pb}$. Lead is associated with microbiome dysregulation in animal models $(33,34)$ and in human studies of adults (35) and children (36), and bile acids regulate the gut microbiome as well as host physiology (37). Similar to our findings, $\mathrm{Pb}$ exposure in mice for 13 weeks decreased bile acid concentrations measured in stool as well as altered the abundances of bacterial genera, most of which were reduced upon $\mathrm{Pb}$ exposure (10). However, this relationship is also likely bidirectional, as the gut microbiome interacts with bile acids (38). In addition, we found a significant negative association between 5- 
medRxiv preprint doi: https://doi.org/10.1101/2021.06.03.21258309; this version posted June 8, 2021. The copyright holder for this preprint (which was not certified by peer review) is the author/funder, who has granted medRxiv a license to display the preprint in perpetuity. It is made available under a CC-BY-NC-ND 4.0 International license .

aminopentanoic acid and blood, tibia, and patella $\mathrm{Pb}$. As 5-aminopentanoic acid is a lysine degradation product formed both endogenously and through bacterial catabolism of lysine, these results may further support a non-transient effect of $\mathrm{Pb}$ on the human microbiome (39).

We observed that acute $\mathrm{Pb}$ exposure (blood $\mathrm{Pb}$ ) was associated with alterations in saturated and polyunsaturated fatty acids and metabolites in the alpha linoleic acid and linolenic acid pathway. Studies on $\mathrm{Pb}$ exposure and lipid alterations in humans are limited. A pilot study of pooled serum samples from occupationally exposed workers to $\mathrm{Pb}$, cadmium, and arsenic found increased levels of very-low-density lipoprotein, decreased low-density lipoprotein, and increased unsaturated fatty acids associated with high heavy metal exposure. These changes in lipid fraction imply disturbance of lipid metabolism (40), though it was not possible to separate the biological effects of individual metals from this mixture. In a single study of 53 postpartum women following delivery, no correlation between fatty acid and Pb levels in maternal blood was observed; notably, that study reported concentrations and ranges of Pb were lower (1.3 [0.6] $\mu \mathrm{g} / \mathrm{dL})$ than in our population of mothers $(2.9[2.6] \mu \mathrm{g} / \mathrm{dL}$, Table 1).

Though human studies of $\mathrm{Pb}$ exposure and lipid dysregulation during pregnancy are limited, several studies in rat dams and pups reported associations consistent with our current study. $\mathrm{Pb}$ exposure in lactating dams resulted in significantly decreased total monounsaturated fatty acids and total fatty acid concentrations; in particular, reduced levels of dihomo-gammalinolenic acid (DGLA), linoleic acid (LA), and eicosapentaenoic acid (EPA) were observed in plasma (41). Further, rats exposed to Pb during pregnancy and lactation had reduced DHA in milk and mammary gland tissues (42), and in pups, $\mathrm{Pb}$ exposure in dam's milk, in combination with an $n-3$ insufficient diet, resulted in a reduction in total saturated fatty acids and total $n-3$ and total $n-6$ fatty acids in plasma i (43). Interestingly, the relationship may be bidirectional: a lower blood $\mathrm{Pb}$ concentration was observed in rats supplemented with a diet rich in $n-3$ and $n-6$ polyunsaturated fatty acids (44). 
medRxiv preprint doi: https://doi.org/10.1101/2021.06.03.21258309; this version posted June 8, 2021. The copyright holder for this preprint (which was not certified by peer review) is the author/funder, who has granted medRxiv a license to display the preprint in perpetuity. It is made available under a CC-BY-NC-ND 4.0 International license .

Acute $\mathrm{Pb}$ exposure was also associated with decreased 2-hydroxybutyrate, a ketone body derived from a-ketobutyrate (alpha-KB) that is produced by amino acid catabolism (threonine and methionine) and glutathione anabolism (cysteine formation pathway) and is metabolized to propionyl-CoA and carbon dioxide (45). 2-hydroxybutyrate levels are hypothesized to be linked with lipid oxidation, oxidative stress, and glutathione synthesis (46). Interestingly, 2-hydroxybutyrate, palmitic acid, palmitoleic acid, stearic, and lactic acid (Table 2) are all linked with gestational diabetes during the second trimester and three months postpartum (47), with 2-hydroxybuytrate indicated as an early biomarker of glucose intolerance $(48,49)$. While these metabolites were higher in mothers with gestational diabetes than controls in the previous studies, which is the opposite direction of our findings, $\mathrm{Pb}$ levels may be associated with alterations in similar pathways. Indeed, $\mathrm{Pb}$ exposure can induce fasting hyperglycemia and glucose intolerance in rats (50). Future mechanistic studies that investigate the role of $\mathrm{Pb}$ on pathways involving a-ketobutyrate, such as phenylalanine and tyrosine metabolism, branched chain amino acids metabolism, and homocysteine metabolism, during pregnancy are encouraged.

Organic environmental exposures are linked with blood $\mathrm{Pb}$ levels in pregnant women, including caffeine (51). Coffee, as well as tea and coca, contain high levels of $\mathrm{Pb}(52)$, possibly due to use of ceramic mugs containing Pb-based glaze (53) or contaminated water used in the coffee-making process and the propensity for $\mathrm{Pb}$ absorption into organic matter (54). We observed that serum caffeine and 1-methyluric acid (a major metabolite of caffeine) were positively associated with blood $\mathrm{Pb}$ levels, but not bone $\mathrm{Pb}$ levels. The association between third-trimester blood $\mathrm{Pb}$ and caffeine most likely represents acute exposures since caffeine has an estimated half-life of up to 11 hours during the last weeks of pregnancy (55). Therefore, caffeine, which has been linked with both beneficial effects in adults and adverse fetal health outcomes (56), may be a particularly important $\mathrm{Pb}$ co-exposure to consider in future studies. 
medRxiv preprint doi: https://doi.org/10.1101/2021.06.03.21258309; this version posted June 8, 2021. The copyright holder for this preprint (which was not certified by peer review) is the author/funder, who has granted medRxiv a license to display the preprint in perpetuity.

It is made available under a CC-BY-NC-ND 4.0 International license .

Betaine was most strongly associated with patella $\mathrm{Pb}$, but also reached marginal significance with blood $\mathrm{Pb}(\mathrm{p}=0.07)$. Betaine is a vital methyl group donor in transmethylation reactions, as part of one-carbon metabolism via the methionine cycle. Since the availability of methyl groups influences methylation (57), betaine may support a mechanistic premise for the role of one-carbon metabolism in observed associations between blood Pb levels and DNA methylation in highly-exposed populations (58), maternal bone Pb levels and DNA methylation in cord blood (59), and in animal exposure models (60). Interestingly, increased betaine levels were observed in the urine of $\mathrm{Pb}$-exposed workers from a $\mathrm{Pb}$-acid battery recycling site (12), suggesting that increased circulating betaine may be a biomarker of chronic or high $\mathrm{Pb}$ exposure levels. Betaine metabolism is also linked to the gut microbiome, specifically probiotic bacterial taxa associated with obesity prevention (Akkermansia, Bifidobacterium, and Lactobacillus) $(61,62)$. The association between betaine and $\mathrm{Pb}$ could be due to $\mathrm{Pb}$-related gut dysbiosis, potentially reducing bacteria that metabolize plant-based molecules.

Our discovery study had several limitations. First, the study included a modest sample size of 99 women in their third trimester of pregnancy from the PROGRESS cohort. While this sample captured an important pregnancy window for $\mathrm{Pb}$ exposure, mothers solely resided in the geographic region of Mexico City, which may limit generalizability to other populations. Second, maternal blood was sampled only once during the third trimester and may not reflect fluctuations in $\mathrm{Pb}$ levels or metabolite profiles. While we also used bone $\mathrm{Pb}$ measurements to investigate associations with cumulative $\mathrm{Pb}$ exposure, we cannot rule out that results were affected by sampling time. Third, this study was limited to the investigation of the main effect of $\mathrm{Pb}$, even though environmental exposures to organics, nutritional compounds, and other toxic metals occur simultaneously, with potential synergistic or antagonistic effects on maternal and fetal biology. Finally, given that our study was cross-sectional, causality cannot be addressed. 
medRxiv preprint doi: https://doi.org/10.1101/2021.06.03.21258309; this version posted June 8, 2021. The copyright holder for this preprint (which was not certified by peer review) is the author/funder, who has granted medRxiv a license to display the preprint in perpetuity.

It is made available under a CC-BY-NC-ND 4.0 International license .

\section{Conclusion}

This discovery study identified dysregulated metabolite profiles during the third trimester of pregnancy that were associated with blood $\mathrm{Pb}$ and bone $\mathrm{Pb}$ levels. In particular, altered 2hydroxybutyrate and metabolites in the alpha linoleic and linolenic acid pathway suggest potential mechanisms linking short-term $\mathrm{Pb}$ exposure to adverse maternal health, such as glucose intolerance and gestational diabetes, and a potential effect of $\mathrm{Pb}$ on altered gut microbiome and microbial metabolism. Further, $\mathrm{Pb}$ exposure levels measured in bone were associated with increased betaine, a methyl donor involved in methylation processes. Together, these results point to several pathways in which short-term and cumulative $\mathrm{Pb}$ exposure may affect maternal and fetal health. Although additional replication studies during pregnancy utilizing larger sample numbers and investigating exposure mixtures are encouraged, these results provide insights to guide future detailed mechanistic studies.

\section{List of Abbreviations}

adrenic acid (AdA)

alpha-linolenic acid (ALA)

arachidonic acid (AA)

body mass index (BMI)

dihomo-gamma-linolenic acid (DGLA)

docosahexaenoic acid (DHA)

docosapentaenoic acid (DPA)

effective number of tests (ENT)

eicosatetraenoic acid (ETA)

eicosapentaenoic acid (EPA)

gamma-linolenic acid (GLA)

interquartile range (IQR) 
lead $(\mathrm{Pb})$

linoleic acid (LA)

liquid chromatography high-resolution mass spectrometry (LC-HRMS)

Mexican Social Security System (Instituto Mexicano del Seguro Social - IMSS)

pooled quality control sample ('pooled QC')

principal components (PCs)

Programming Research in Obesity, Growth, Environment, and Social Stressors (PROGRESS)

reverse phase $(\mathrm{RP})$

stearidonic acid (SDA)

\section{Declarations}

Ethics approval and consent to participate: Procedures were approved by institutional review boards at the Harvard School of Public Health, Icahn School of Medicine at Mount Sinai, and the Mexican National Institute of Public Health. Women provided written informed consent in Spanish.

Consent for publication: Not applicable.

Availability of data and materials: The data that support the findings of this study are available from the PROGRESS study team (PI: Robert O. Wright, robert.wright@mssm.edu), but restrictions apply to the availability of these data. Data are available upon reasonable request.

Competing interests: The authors declare that they have no competing interests. 
medRxiv preprint doi: https://doi.org/10.1101/2021.06.03.21258309; this version posted June 8, 2021. The copyright holder for this preprint (which was not certified by peer review) is the author/funder, who has granted medRxiv a license to display the preprint in perpetuity. It is made available under a CC-BY-NC-ND 4.0 International license.

Funding: This work was supported by the National Institutes of Health (R01 ES014930, R01 ES013744, P30 ES023515, U2CES030859, T32 HD049311, R01 ES031117, R21 ES030882) and the National Institute of Public Health/Ministry of Health of Mexico.

Authors' contributions: MN and LP contributed to the conception and design of the work, data interpretation, and drafting and revision of the manuscript. SE contributed to the drafting and revision of the manuscript. AJ contributed to the data analysis and revision of the manuscript. GD and CA contributed to the sample analysis, data acquisition, and revision of the manuscript. AC, HL-F, MT-R, RW contributed to the conception and design of the work, data acquisition, and revision of the manuscript. All authors read and approved the final manuscript.

Acknowledgements: We thank the ABC (American British Cowdray Medical Center) in Mexico for providing research facilities and all of the PROGRESS staff and study participants. 
medRxiv preprint doi: https://doi.org/10.1101/2021.06.03.21258309; this version posted June 8, 2021. The copyright holder for this preprint (which was not certified by peer review) is the author/funder, who has granted medRxiv a license to display the preprint in perpetuity. It is made available under a CC-BY-NC-ND 4.0 International license .

\section{References}

1. Betts Kellyn S. CDC Updates Guidelines for Children's Lead Exposure. Environ Health Perspect. 2012 Jul 1;120(7):a268-a268.

2. Abadin H, Ashizawa A, Stevens Y-W, Llados F, Diamond G, Sage G, et al. Toxicological Profile for Lead [Internet]. Atlanta (GA): Agency for Toxic Substances and Disease Registry (US); 2007 [cited 2021 Apr 12]. (Agency for Toxic Substances and Disease Registry (ATSDR) Toxicological Profiles). Available from: http://www.ncbi.nlm.nih.gov/books/NBK158766/

3. Lidsky TI, Schneider JS. Lead neurotoxicity in children: basic mechanisms and clinical correlates. Brain. 2003 Jan 1;126(1):5-19.

4. Ramírez Ortega D, González Esquivel DF, Blanco Ayala T, Pineda B, Gómez Manzo S, Marcial Quino J, et al. Cognitive Impairment Induced by Lead Exposure during Lifespan: Mechanisms of Lead Neurotoxicity. Toxics. 2021 Jan 28;9(2).

5. Zeng X, Huo X, Xu X, Liu D, Wu W. E-waste lead exposure and children's health in China. Sci Total Environ. 2020 Sep 10;734:139286.

6. Wani AL, Ara A, Usmani JA. Lead toxicity: a review. Interdiscip Toxicol. 2015;8(2):55-64.

7. Tong S, von Schirnding YE, Prapamontol T. Environmental lead exposure: a public health problem of global dimensions. Bull World Health Organ. 2000;78(9):1068-77.

8. Dórea JG. Environmental exposure to low-level lead $(\mathrm{Pb})$ co-occurring with other neurotoxicants in early life and neurodevelopment of children. Environ Res. 2019 Oct;177:108641.

9. Levin-Schwartz Y, Gennings C, Schnaas L, Del Carmen Hernández Chávez M, Bellinger DC, Téllez-Rojo MM, et al. Time-varying associations between prenatal metal mixtures and rapid visual processing in children. Environ Health Glob Access Sci Source. 2019 Oct $30 ; 18(1): 92$.

10. Gao B, Chi L, Mahbub R, Bian X, Tu P, Ru H, et al. Multi-Omics Reveals that Lead 
medRxiv preprint doi: https://doi.org/10.1101/2021.06.03.21258309; this version posted June 8, 2021. The copyright holder for this preprint (which was not certified by peer review) is the author/funder, who has granted medRxiv a license to display the preprint in perpetuity. It is made available under a CC-BY-NC-ND 4.0 International license .

Exposure Disturbs Gut Microbiome Development, Key Metabolites, and Metabolic Pathways. Chem Res Toxicol. 2017 Apr 17;30(4):996-1005.

11. Mani MS, Joshi MB, Shetty RR, DSouza VL, Swathi M, Kabekkodu SP, et al. Lead exposure induces metabolic reprogramming in rat models. Toxicol Lett. 2020 Dec 15;335:11-27.

12. Eguchi A, Nomiyama K, Sakurai K, Kim Trang PT, Viet PH, Takahashi S, et al. Alterations in urinary metabolomic profiles due to lead exposure from a lead-acid battery recycling site. Environ Pollut. 2018 Nov 1;242:98-105.

13. Kelly RS, Bayne H, Spiro A, Vokonas P, Sparrow D, Weiss ST, et al. Metabolomic signatures of lead exposure in the VA Normative Aging Study. Environ Res. 2020 Nov;190:110022.

14. Agency for Toxic Substances and Disease Registry (ASTDR). Toxicological profile for lead [Internet]. Atlanta (GA): U.S. Department of Health and Human Services; 2020 Aug [cited 2021 Apr 12]. Available from: https://stacks.cdc.gov/view/cdc/95222

15. Renzetti S, Just AC, Burris HH, Oken E, Amarasiriwardena C, Svensson K, et al. The association of lead exposure during pregnancy and childhood anthropometry in the Mexican PROGRESS cohort. Environ Res. 2017 Jan 1;152:226-32.

16. $\mathrm{Hu} \mathrm{H}$, Milder FL, Burger DE. The use of $\mathrm{K} \mathrm{X}$-ray fluorescence for measuring lead burden in epidemiological studies: high and low lead burdens and measurement uncertainty. Environ Health Perspect. 1991 Aug;94:107-10.

17. Hu H, Rabinowitz M, Smith D. Bone lead as a biological marker in epidemiologic studies of chronic toxicity: conceptual paradigms. Environ Health Perspect. 1998 Jan;106(1):1-8.

18. Hu J, Lesseur C, Miao Y, Manservisi F, Panzacchi S, Mandrioli D, et al. Low-dose exposure of glyphosate-based herbicides disrupt the urine metabolome and its interaction with gut microbiota. Sci Rep. 2021 Feb 5;11(1):3265.

19. Yu M, Dolios G, Yong-Gonzalez V, Björkqvist O, Colicino E, Halfvarson J, et al. Untargeted metabolomics profiling and hemoglobin normalization for archived newborn dried blood 
medRxiv preprint doi: https://doi.org/10.1101/2021.06.03.21258309; this version posted June 8, 2021. The copyright holder for this preprint (which was not certified by peer review) is the author/funder, who has granted medRxiv a license to display the preprint in perpetuity. It is made available under a CC-BY-NC-ND 4.0 International license .

spots from a refrigerated biorepository. J Pharm Biomed Anal. 2020 Nov 30;191:113574.

20. Nyholt DR. A simple correction for multiple testing for single-nucleotide polymorphisms in linkage disequilibrium with each other. Am J Hum Genet. 2004 Apr;74(4):765-9.

21. Li M-X, Yeung JMY, Cherny SS, Sham PC. Evaluating the effective numbers of independent tests and significant $p$-value thresholds in commercial genotyping arrays and public imputation reference datasets. Hum Genet. 2012 May;131(5):747-56.

22. Chong J, Soufan O, Li C, Caraus I, Li S, Bourque G, et al. MetaboAnalyst 4.0: towards more transparent and integrative metabolomics analysis. Nucleic Acids Res. 2018 Jul $2 ; 46(\mathrm{~W} 1): W 486-94$.

23. Jewison T, Su Y, Disfany FM, Liang Y, Knox C, Maciejewski A, et al. SMPDB 2.0: big improvements to the Small Molecule Pathway Database. Nucleic Acids Res. 2014 Jan;42(Database issue):D478-484.

24. Ettinger Adrienne S., Egan Kathryn B., Homa David M., Brown Mary Jean. Blood Lead Levels in U.S. Women of Childbearing Age, 1976-2016. Environ Health Perspect. 128(1):017012.

25. Kosnett MJ, Wedeen RP, Rothenberg SJ, Hipkins KL, Materna BL, Schwartz BS, et al. Recommendations for Medical Management of Adult Lead Exposure. Environ Health Perspect. 2007 Mar;115(3):463-71.

26. CDC - Adult Blood Lead Epidemiology and Surveillance (ABLES): Reference Blood Lead Levels (BLLs) for Adults in the U. S. $\square$ : NIOSH Workplace Safety and Health Topic [Internet]. 2021 [cited 2021 May 21]. Available from:

https://www.cdc.gov/niosh/topics/ables/ReferenceBloodLevelsforAdults.html

27. Schütz A, Bergdahl IA, Ekholm A, Skerfving S. Measurement by ICP-MS of lead in plasma and whole blood of lead workers and controls. Occup Environ Med. 1996 Nov;53(11):73640.

28. Barry PSI, Mossman DB. Lead concentrations in human tissues. Br J Ind Med. 1970 
medRxiv preprint doi: https://doi.org/10.1101/2021.06.03.21258309; this version posted June 8, 2021. The copyright holder for this preprint

(which was not certified by peer review) is the author/funder, who has granted medRxiv a license to display the preprint in perpetuity.

It is made available under a CC-BY-NC-ND 4.0 International license .

Oct;27(4):339-51.

29. Hernández-Avila M, Smith D, Meneses F, Sanin LH, Hu H. The influence of bone and blood lead on plasma lead levels in environmentally exposed adults. Environ Health Perspect. 1998 Aug;106(8):473-7.

30. Ettinger AS, Lamadrid-Figueroa H, Mercado-García A, Kordas K, Wood RJ, Peterson KE, et al. Effect of calcium supplementation on bone resorption in pregnancy and the early postpartum: a randomized controlled trial in Mexican Women. Nutr J. 2014 Dec;13(1):116.

31. Téllez-Rojo MM, Hernández-Avila M, Lamadrid-Figueroa H, Smith D, Hernández-Cadena L, Mercado A, et al. Impact of Bone Lead and Bone Resorption on Plasma and Whole Blood Lead Levels during Pregnancy. Am J Epidemiol. 2004 Oct 1;160(7):668-78.

32. Amaral JH, Rezende VB, Quintana SM, Gerlach RF, Barbosa F, Tanus-Santos JE. The relationship between blood and serum lead levels in peripartum women and their respective umbilical cords. Basic Clin Pharmacol Toxicol. 2010 Dec;107(6):971-5.

33. Xia J, Lu L, Jin C, Wang S, Zhou J, Ni Y, et al. Effects of short term lead exposure on gut microbiota and hepatic metabolism in adult zebrafish. Comp Biochem Physiol Part C Toxicol Pharmacol. 2018 Jul 1;209:1-8.

34. Wu J, Wen XW, Faulk C, Boehnke K, Zhang H, Dolinoy DC, et al. Perinatal Lead Exposure Alters Gut Microbiota Composition and Results in Sex-specific Bodyweight Increases in Adult Mice. Toxicol Sci Off J Soc Toxicol. 2016 Jun;151(2):324-33.

35. Eggers S, Safdar N, Sethi AK, Suen G, Peppard PE, Kates AE, et al. Urinary lead concentration and composition of the adult gut microbiota in a cross-sectional populationbased sample. Environ Int. 2019 Dec;133(Pt A):105122.

36. Sitarik AR, Arora M, Austin C, Bielak LF, Eggers S, Johnson CC, et al. Fetal and early postnatal lead exposure measured in teeth associates with infant gut microbiota. Environ Int. 2020 Nov 1;144:106062.

37. Ridlon JM, Kang DJ, Hylemon PB, Bajaj JS. Bile Acids and the Gut Microbiome. Curr Opin 
medRxiv preprint doi: https://doi.org/10.1101/2021.06.03.21258309; this version posted June 8, 2021. The copyright holder for this preprint

(which was not certified by peer review) is the author/funder, who has granted medRxiv a license to display the preprint in perpetuity.

It is made available under a CC-BY-NC-ND 4.0 International license .

Gastroenterol. 2014 May;30(3):332-8.

38. Winston JA, Theriot CM. Diversification of host bile acids by members of the gut microbiota. Gut Microbes. 2019 Oct 9;11(2):158-71.

39. Knorr S, Sinn M, Galetskiy D, Williams RM, Wang C, Müller N, et al. Widespread bacterial lysine degradation proceeding via glutarate and L-2-hydroxyglutarate. Nat Commun. 2018 Nov 29;9(1):5071.

40. Dudka I, Kossowska B, Senhadri H, Latajka R, Hajek J, Andrzejak R, et al. Metabonomic analysis of serum of workers occupationally exposed to arsenic, cadmium and lead for biomarker research: A preliminary study. Environ Int. 2014 Jul 1;68:71-81.

41. Sun-Young L, Loewke J, Doherty JD, Salem N. Preferential Effect of Lead Exposure During Lactation on Non-Essential Fatty Acids in Maternal Organs. Lipids. 2005 Jul;40(7):685-93.

42. Hossain S, Hussain J, Bhowmick S, Sarkar M, Basunia M, Al Mamun A, et al. Docosahexaenoic Acid (DHA, C22:6, w-3) Composition of Milk and Mammary Gland Tissues of Lactating Mother Rats Is Severely Affected by Lead (Pb) Exposure. Biol Trace Elem Res. 2020 Jun 1;195(2):525-34.

43. Lim S-Y, Doherty JD, Salem N Jr. Lead Exposure and (n-3) Fatty Acid Deficiency during Rat Neonatal Development Alter Liver, Plasma, and Brain Polyunsaturated Fatty Acid Composition. J Nutr. 2005 May 1;135(5):1027-33.

44. Baranowska-Bosiacka I, Kosińska I, Jamioł D, Gutowska I, Prokopowicz A, Rębacz-Maron E, et al. Environmental Lead (Pb) Exposure Versus Fatty Acid Content in Blood and Milk of the Mother and in the Blood of Newborn Children. Biol Trace Elem Res. 2016;170:279-87.

45. Landaas S. The formation of 2-hydroxybutyric acid in experimental animals. Clin Chim Acta. 1975 Jan 6;58(1):23-32.

46. Sekhar RV, McKay SV, Patel SG, Guthikonda AP, Reddy VT, Balasubramanyam A, et al. Glutathione Synthesis Is Diminished in Patients With Uncontrolled Diabetes and Restored by Dietary Supplementation With Cysteine and Glycine. Diabetes Care. 2011 Jan 
medRxiv preprint doi: https://doi.org/10.1101/2021.06.03.21258309; this version posted June 8, 2021. The copyright holder for this preprint

(which was not certified by peer review) is the author/funder, who has granted medRxiv a license to display the preprint in perpetuity. It is made available under a CC-BY-NC-ND 4.0 International license .

$1 ; 34(1): 162-7$.

47. Dudzik D, Zorawski M, Skotnicki M, Zarzycki W, García A, Angulo S, et al. GC-MS based Gestational Diabetes Mellitus longitudinal study: Identification of 2-and 3-hydroxybutyrate as potential prognostic biomarkers. J Pharm Biomed Anal. 2017 Sep 10;144:90-8.

48. Ferrannini E, Natali A, Camastra S, Nannipieri M, Mari A, Adam K-P, et al. Early Metabolic Markers of the Development of Dysglycemia and Type 2 Diabetes and Their Physiological Significance. Diabetes. 2013 May 1;62(5):1730-7.

49. Gall WE, Beebe K, Lawton KA, Adam K-P, Mitchell MW, Nakhle PJ, et al. alphahydroxybutyrate is an early biomarker of insulin resistance and glucose intolerance in a nondiabetic population. PloS One. 2010 May 28;5(5):e10883.

50. Tyrrell JB, Hafida S, Stemmer P, Adhami A, Leff $\mathrm{T}$. Lead $(\mathrm{Pb})$ exposure promotes diabetes in obese rodents. J Trace Elem Med Biol. 2017 Jan 1;39:221-6.

51. Taylor CM, Golding J, Hibbeln J, Emond AM. Environmental Factors Predicting Blood Lead Levels in Pregnant Women in the UK: The ALSPAC Study. PLOS ONE. 2013 Sep 5;8(9):e72371 .

52. Scientific Opinion on Lead in Food. EFSA J. 2010;8(4):1570.

53. Pantic I, Tamayo-Ortiz M, Rosa-Parra A, Bautista-Arredondo L, Wright RO, Peterson KE, et al. Children's Blood Lead Concentrations from 1988 to 2015 in Mexico City: The Contribution of Lead in Air and Traditional Lead-Glazed Ceramics. Int J Environ Res Public Health. 2018 Sep 30;15(10).

54. Siu Y, Mejia G, Mejia-Saavedra J, Pohlan J, Sokolov M. Heavy Metals in Wet Method Coffee Processing Wastewater in Soconusco, Chiapas, Mexico. Bull Environ Contam Toxicol. 2007 May 1;78(5):400-4.

55. Knutti R, Rothweiler H, Schlatter $\mathrm{C}$. The effect of pregnancy on the pharmacokinetics of caffeine. Arch Toxicol Suppl Arch Toxikol Suppl. 1982;5:187-92.

56. Poole R, Kennedy OJ, Roderick P, Fallowfield JA, Hayes PC, Parkes J. Coffee consumption 
medRxiv preprint doi: https://doi.org/10.1101/2021.06.03.21258309; this version posted June 8, 2021. The copyright holder for this preprint

(which was not certified by peer review) is the author/funder, who has granted medRxiv a license to display the preprint in perpetuity.

It is made available under a CC-BY-NC-ND 4.0 International license .

and health: umbrella review of meta-analyses of multiple health outcomes. BMJ. 2017 Nov 22;359:j5024.

57. Zeisel SH. Choline, Other Methyl-Donors and Epigenetics. Nutrients [Internet]. 2017 Apr 29 [cited 2021 Mar 29];9(5). Available from:

https://www.ncbi.nlm.nih.gov/pmc/articles/PMC5452175/

58. Yohannes YB, Nakayama SMM, Yabe J, Nakata H, Toyomaki H, Kataba A, et al. Blood lead levels and aberrant DNA methylation of the ALAD and p16 gene promoters in children exposed to environmental-lead. Environ Res. 2020 Sep 1;188:109759.

59. Pilsner JR, Hu H, Ettinger A, Sánchez BN, Wright RO, Cantonwine D, et al. Influence of Prenatal Lead Exposure on Genomic Methylation of Cord Blood DNA. Environ Health Perspect. 2009 Sep;117(9):1466-71.

60. Basha MR, Wei W, Bakheet SA, Benitez N, Siddiqi HK, Ge Y-W, et al. The fetal basis of amyloidogenesis: exposure to lead and latent overexpression of amyloid precursor protein and beta-amyloid in the aging brain. J Neurosci Off J Soc Neurosci. 2005 Jan 26;25(4):8239.

61. Koistinen VM, Kärkkäinen O, Borewicz K, Zarei I, Jokkala J, Micard V, et al. Contribution of gut microbiota to metabolism of dietary glycine betaine in mice and in vitro colonic fermentation. Microbiome. 2019 Jul 10;7(1):103.

62. Du J, Zhang P, Luo J, Shen L, Zhang S, Gu H, et al. Dietary betaine prevents obesity through gut microbiota-drived microRNA-378a family. Gut Microbes. 2021 Jan 1;13(1):1-19. 
medRxiv preprint doi: https://doi.org/10.1101/2021.06.03.21258309; this version posted June 8, 2021. The copyright holder for this preprint (which was not certified by peer review) is the author/funder, who has granted medRxiv a license to display the preprint in perpetuity.

It is made available under a CC-BY-NC-ND 4.0 International license .

Table 1. Descriptive characteristics for PROGRESS mothers in current study $(\mathrm{N}=99)$.

\begin{tabular}{|l|l|l|}
\hline Characteristics & Level/Unit & $\begin{array}{l}\text { Median (IQR) } \\
\text { or N (\%) }\end{array}$ \\
\hline Demographics & & \\
\hline Age at recruitment & Years & $27.7(6.8)$ \\
\hline BMI in 3 ${ }^{\text {rd } \text { trimester }}$ & $\mathrm{kg} / \mathrm{m}^{2}$ & $28.6(5.0)$ \\
\hline Maternal Education & $<$ High School & $37(37 \%)$ \\
\hline & High School & $38(38 \%)$ \\
\hline & $>$ High School & $24(24 \%)$ \\
\hline Smoke exposure & Yes & $30(30 \%)$ \\
\hline Season of last menstrual period & Dry/cold & $29(29 \%)$ \\
\hline & Dry/warm & $22(22 \%)$ \\
\hline Patella Pb, 1 month postpartum & Rainy & $48(48 \%)$ \\
\hline Blood $\mathbf{P b}, 3 r d$ trimester & & \\
\hline Tibia Pb, 1 month postpartum & $\mu \mathrm{Pg} / \mathrm{g} / \mathrm{dL}$ & $2.9(2.6)$ \\
\hline & $\mu \mathrm{g} / \mathrm{g}$ & $2.5(7.3)$ \\
\hline
\end{tabular}


Table 2. Serum metabolites associated with blood $\mathrm{Pb}$ in the $3^{\text {rd }}$ trimester.

\begin{tabular}{|c|c|c|c|}
\hline Metabolite subclass & Compound $^{a}$ & Estimate (SE) & P \\
\hline \multirow[t]{12}{*}{ Fatty acids and conjugates ${ }^{\star * *}$} & Myristic acid & $-0.073(0.024)$ & 2.63E-03 \\
\hline & Stearic acid & $-0.043(0.014)$ & 3.02E-03 \\
\hline & Adrenic acid & $-0.058(0.019)$ & 3.37E-03 \\
\hline & Palmitoleic acid & $-0.097(0.032)$ & 3.56E-03 \\
\hline & $\begin{array}{l}\text { Oleic acid / Elaidic acid / Petroselinic } \\
\text { acid }\end{array}$ & $-0.051(0.020)$ & 1.25E-02 \\
\hline & Arachidonic acid & $-0.040(0.016)$ & $1.52 \mathrm{E}-02$ \\
\hline & Lauric acid & $-0.058(0.023)$ & 1.53E-02 \\
\hline & Dihomo-Gamma-Linolenic acid & $-0.040(0.016)$ & 1.69E-02 \\
\hline & Margaric acid / Hexadecanol & $-0.046(0.020)$ & 2.14E-02 \\
\hline & Arachidic acid & $-0.036(0.016)$ & 2.91E-02 \\
\hline & Palmitic acid & $-0.041(0.014)$ & 5.14E-03 \\
\hline & Eicosapentaenoic acid & $-0.049(0.024)$ & 4.40E-02 \\
\hline \multirow[t]{7}{*}{ Amino acids, peptides, and analogues ${ }^{* \star *}$} & N-Acetylasparagine & $0.152(0.052)$ & 4.09E-03 \\
\hline & 5-Aminopentanoate & $-0.137(0.053)$ & 1.16E-02 \\
\hline & N-Acetylalanine & $-0.047(0.019)$ & 1.48E-02 \\
\hline & Asparagine & $-0.035(0.016)$ & 3.05E-02 \\
\hline & $\mathrm{N}$-Acetylmethionine & $-0.084(0.040)$ & 3.94E-02 \\
\hline & Creatine & $-0.064(0.031)$ & 4.00E-02 \\
\hline & L-Leucine & $-0.039(0.019)$ & 4.16E-02 \\
\hline \multirow[t]{4}{*}{ Purines and purine derivatives ${ }^{\star * *}$} & Hypoxanthine & $-0.047(0.014)$ & 1.26E-03 \\
\hline & 7-Methylguanine & $-0.015(0.006)$ & 1.70E-02 \\
\hline & Caffeine & $0.193(0.080)$ & 1.84E-02 \\
\hline & 1-Methyluric acid & $0.131(0.062)$ & 3.85E-02 \\
\hline \multirow[t]{2}{*}{ Bile acids, alcohols and derivatives } & Glycocholic acid & $0.079(0.035)$ & 2.73E-02 \\
\hline & Glycochenodeoxycholic acid & $0.075(0.038)$ & 4.93E-02 \\
\hline Alpha hydroxy acids and derivatives & 2-Hydroxybutyrate & $-0.055(0.016)$ & 6.50E-04 \\
\hline Dicarboxylic acids and derivatives & Succinate & $-0.062(0.024)$ & 1.17E-02 \\
\hline Organosulfonic acids and derivatives & Taurine & $-0.037(0.015)$ & 1.26E-02 \\
\hline Benzoic acids and derivatives & MBP (Mono-n-butyl phthalate) & $-0.076(0.036)$ & 3.85E-02 \\
\hline
\end{tabular}


medRxiv preprint doi: https://doi.org/10.1101/2021.06.03.21258309; this version posted June 8, 2021. The copyright holder for this preprint (which was not certified by peer review) is the author/funder, who has granted medRxiv a license to display the preprint in perpetuity. It is made available under a CC-BY-NC-ND 4.0 International license .

\begin{tabular}{|l|l|l|l|} 
Linoleic acids and derivatives & $\begin{array}{l}\text { Alpha-linolenic acid (ALA) / Gamma- } \\
\text { Linolenic acid (GLA) }\end{array}$ & $-0.079(0.032)$ & $1.50 \mathrm{E}-02$ \\
\hline Fatty acid esters & Acetylcarnitine & $-0.049(0.017)$ & $4.16 \mathrm{E}-03$ \\
\hline
\end{tabular}

${ }^{* * *}$ Significantly-enriched $($ Holm-Bonferroni $\mathrm{p}<0.05)$ subclass from enrichment analysis in MetaboAnalyst; a. Compounds that co-eluted and could not be discriminated indicated with "/" 
Table 3. Serum metabolites associated with patella and tibia $\mathrm{Pb}$.

\begin{tabular}{|c|c|c|c|c|}
\hline \multirow[b]{2}{*}{ Compound } & \multicolumn{2}{|l|}{ Patella Pb } & \multicolumn{2}{|l|}{ Tibia Pb } \\
\hline & Estimate (SE) & $\mathbf{P}$ & Estimate (SE) & $\mathbf{P}$ \\
\hline \multicolumn{5}{|l|}{ Significant in patella and tibia } \\
\hline 5-Aminopentanoic acid & $-0.049(0.015)$ & $1.82 \mathrm{E}-03$ & $-0.049(0.022)$ & $2.46 \mathrm{E}-02$ \\
\hline L-Arginine & $-0.010(0.005)$ & 4.70E-02 & $-0.015(0.007)$ & 2.74E-02 \\
\hline \multicolumn{5}{|l|}{ Significant in patella } \\
\hline Betaine & $0.031(0.009)$ & 5.31E-04 & $0.018(0.014)$ & 0.19 \\
\hline Corticosterone & $-0.102(0.039)$ & 1.12E-02 & $-0.089(0.056)$ & 0.11 \\
\hline Biliverdin & $0.017(0.007)$ & 1.97E-02 & $0.007(0.010)$ & 0.45 \\
\hline Oxoproline & $0.012(0.005)$ & 2.05E-02 & $0.004(0.007)$ & 0.60 \\
\hline Pyroglutamate & $0.012(0.005)$ & 2.09E-02 & $0.004(0.007)$ & 0.60 \\
\hline Lithocholic acid & $-0.056(0.026)$ & 3.25E-02 & $-0.001(0.036)$ & 0.99 \\
\hline 7-Methylguanine & $-0.004(0.002)$ & 3.29E-02 & $-0.003(0.003)$ & 0.34 \\
\hline POV-PC & $-0.018(0.008)$ & $3.42 \mathrm{E}-02$ & $-0.022(0.011)$ & 0.05 \\
\hline N-Acetylneuraminate & $-0.049(0.024)$ & 4.45E-02 & $-0.024(0.034)$ & 0.47 \\
\hline \multicolumn{5}{|l|}{ Significant in tibia } \\
\hline 1-Linoleoylglycerol & $0.020(0.018)$ & 0.29 & $0.083(0.023)$ & $6.60 \mathrm{E}-04$ \\
\hline Glycochenodeoxycholic acid & $0.009(0.012)$ & 0.44 & $0.044(0.016)$ & 6.83E-03 \\
\hline Docosahexaenoic acid (DHA) & $-0.009(0.006)$ & 0.16 & $-0.022(0.008)$ & $9.21 \mathrm{E}-03$ \\
\hline Allantoin & $-0.011(0.007)$ & 0.13 & $-0.026(0.010)$ & $9.56 \mathrm{E}-03$ \\
\hline Glycocholic acid & $0.015(0.011)$ & 0.18 & $0.037(0.015)$ & $1.74 \mathrm{E}-02$ \\
\hline Malic acid & $0.011(0.016)$ & 0.47 & $0.049(0.021)$ & 2.07E-02 \\
\hline MEP (Mono-ethyl phthalate) & $0.025(0.027)$ & 0.36 & $0.085(0.037)$ & 2.32E-02 \\
\hline Oleoyl-Glycerol & $-0.011(0.010)$ & 0.26 & $-0.030(0.013)$ & 2.79E-02 \\
\hline L-Isoleucine & $0.007(0.005)$ & 0.17 & $0.014(0.007)$ & 3.66E-02 \\
\hline Indole-3-Carboxylic acid & $0.004(0.006)$ & 0.54 & $-0.017(0.008)$ & 3.82E-02 \\
\hline Erucic acid & $-0.006(0.006)$ & 0.32 & $-0.017(0.008)$ & 3.96E-02 \\
\hline 2-Undecanone & $0.008(0.005)$ & 0.07 & $0.013(0.006)$ & 4.10E-02 \\
\hline
\end{tabular}


Figure 1. Distributions and correlations of $\mathrm{Pb}$ in 3rd trimester blood, tibia, and patella.
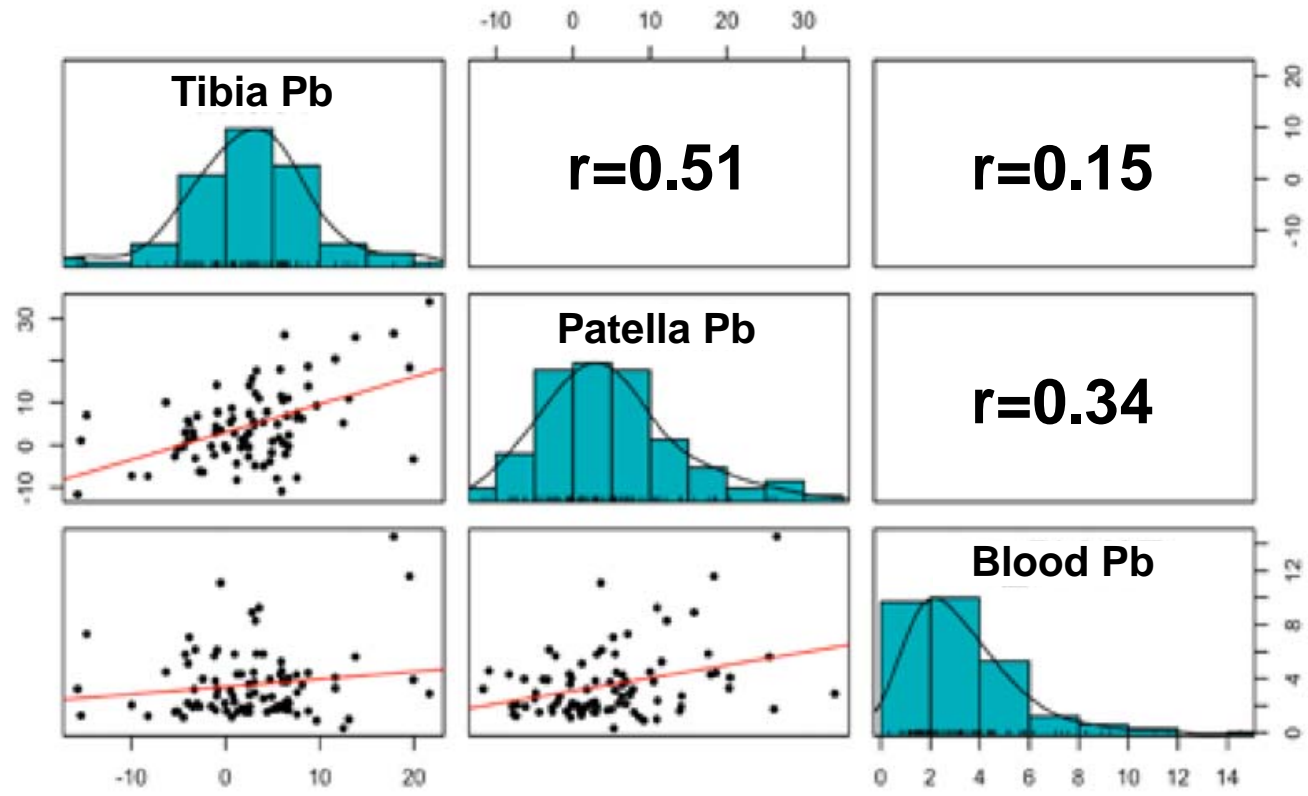
medRxiv preprint doi: https://doi.org/10.1101/2021.06.03.21258309; this version posted June 8, 2021. The copyright holder for this preprint (which was not certified by peer review) is the author/funder, who has granted medRxiv a license to display the preprint in perpetuity.

It is made available under a CC-BY-NC-ND 4.0 International license .

Figure 2. Pathway enrichment analysis of serum metabolites associated with blood $\mathrm{Pb}$ identifies the alpha linolenic acid and linoleic acid pathway. Metabolites negatively associated with blood $\mathrm{Pb}(\mathrm{p}<0.05)$ levels shown in blue. ${ }^{\mathrm{a}} \mathrm{ALA}$ and GLA co-eluted; ${ }^{\mathrm{b}} \mathrm{A}$ and DHA were negatively associated with blood $\mathrm{Pb}$ at marginal significance $(\mathrm{p}=0.06)$. ALA: alpha linolenic acid; SDA: stearidonic acid; ETA: eicosatetraenoic acid; EPA: eicosapentaenoic acid; DPA: docosapentaenoic acid; DHA: docosahexaenoic acid; LA: linoleic acid; GLA: gamma-linolenic acid; DGLA: dihomo-gamma-linolenic acid; AA: arachidonic acid; AdA: adrenic acid.

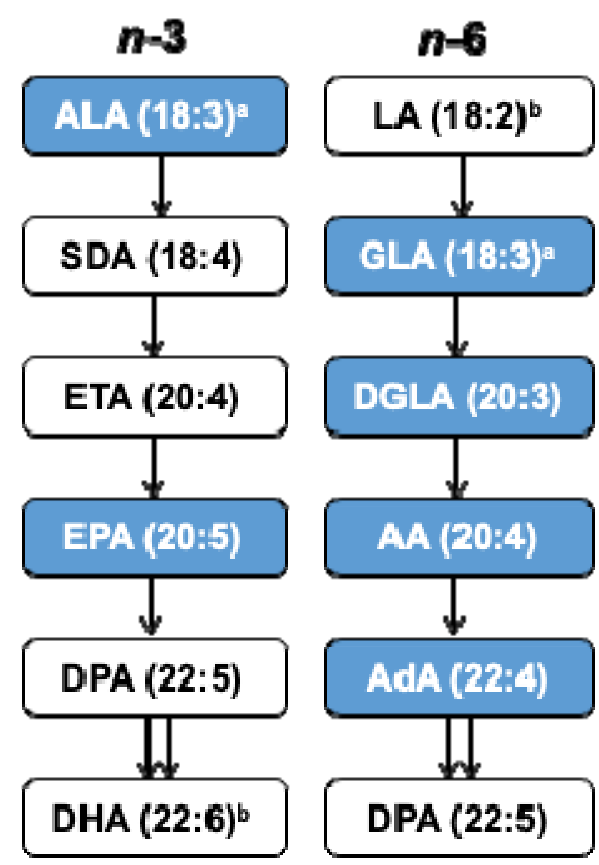


Figure 3. Scatterplots of 5-aminopentanoic acid versus $\mathrm{Pb}$ in $3^{\text {rd }}$ trimester blood, tibia, and patella.

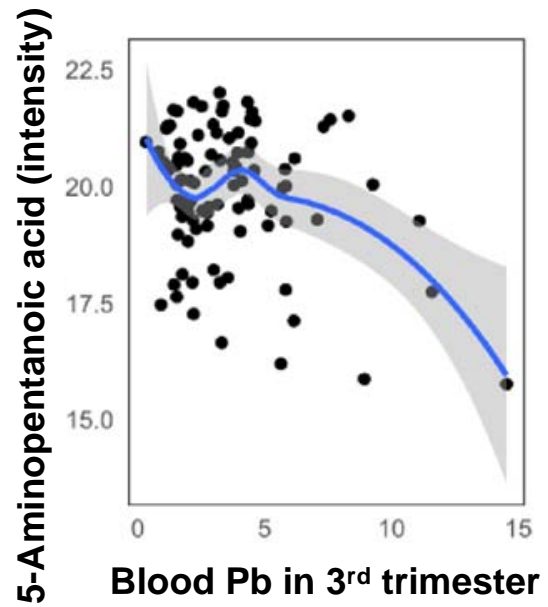

$(\mu \mathrm{g} / \mathrm{dL})$
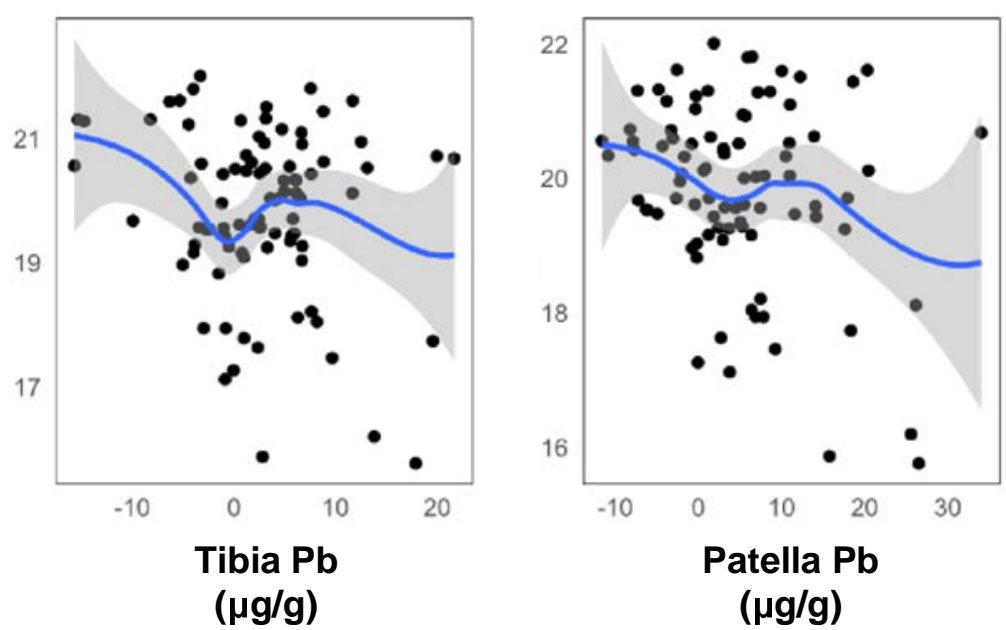